\title{
QUALITY ATTRIBUTES OF CHICKEN BURGER FORMULATED WITH DIFFERENT LEVELS OF GIZZARD OR MECHANICAL DEBONED CHICKEN MEAT DURING FROZEN STORAGE
}

\author{
Mai M. El-Kordy(1), A. S. Osheba(1), Amal A. Hassan ${ }^{(2)}$ \\ and A. E. El-beltagy (2) \\ (1) Meat and Fish Tech. Res. Department, Food Tech. Res. Institute, Agricultural Research \\ Center, Giza Egypt 12613 \\ (2) Food Science and Technology, Faculty of Agriculture, Menoufia University, Shibin El-Kom, \\ Egypt.
}

Received: Aug. 5, 2019

Accepted: Aug. 27, 2019

ABSTRACT: The chicken burgers were formulated with 20, 40 and $60 \%$ levels of gizzard or mechanically deboned chicken meat (MDCM). The chemical, physicochemical, microbiological and sensory properties of chicken burgers were evaluated during storage at $-18 \pm 1^{\circ} \mathrm{C}$ for 6 months. The chicken burgers formulated with gizzard had higher $(p \leq 0.05)$ moisture (70.56\%), crude protein (17.23\%), total ash $(2.97 \%)$ and lower $(p \leq 0.05)$ total volatile nitrogen $(14.46 \mathrm{mg} / 100 \mathrm{~g})$, thiobarbituric acid $(0.54 \mathrm{mg}$ malonaldehyde/ $\mathrm{kg}$ sample), peroxide value (3.74 meq/kg fat ), $\mathrm{pH}$ (6.42), water holding capacity value (3.50 $\mathrm{cm} 2 / 0.3 \mathrm{~g})$ and plasticity $(3.11 \mathrm{~cm} 2 / 0.3 \mathrm{~g})$ than chicken burgers formulated with MDCM. The crude protein and total ash contents of the chicken burgers were $(p \leq 0.05)$ decreased and crude fat, total volatile nitrogen, and thiobarbituric acid increased ( $p \leq$ $0.05)$ by increasing the levels of gizzard or MDCM. Increasing the levels of gizzard in the chicken burgers led to reducing total bacterial count, psychrophilic bacteria and Staphylococcus aureus counts compared with control chicken burger. However, MDCM had an opposite trend. The sensory properties of the chicken burgers formulated with gizzard had rating scores described as like very much (7.52-8.05). However, chicken burgers formulated with MDCM had rating scores ranged between like moderately (6.80) and like very much (7.03-7.64). Although TVN, TBA, PV and microbial load of the chicken burgers increased and sensory properties decreased during the storage period, the chicken burger still had an acceptable quality.

Key word: Chicken burger, chicken meat, gizzard, mechanical deboned chicken meat.

\section{INTRODUCTION}

Poultry meat is a very popular food commodity around the world and its consumption has increased over the last decades. In many countries some of the reasons for the popularity are the relatively low cost of production, low fat content and the high nutritional value of poultry meat (Chouliara et al., 2007). However, the poultry industry generates by-products which are generally underutilized, for example poultry liver, gizzard and mechanical deboned poultry meat.
Gizzard is one of the principal edible by-products of poultry processing which is being marketed as variety meats along with dressed chicken. It forms nearly $3 \%$ of dressed chicken (Charonpong and Chen 1980) and as such it is less preferred by the consumer due to its peculiar flavor and texture. Gizzard contains approximately $20 \%$ proteins (Kondaiah and Panda 1987 and Rao et al., 1994) and has potential for using in cost effective, convenient ready to eat chicken products. 
Mai M. El-Kordy, et al.,

Mechanically deboned chicken meat (MDCM) is obtained by deboning or separation techniques of edible tissue on chicken bones. Generally, MDCM consist high amount of lipid and ash, when compared to fresh meat, and it also contains free heme groups because bone marrow and bone components are included in MDCM (Ockerman and Hansen, 2000). For these reasons, MDCM is vulnerable to oxidation and spoilage, and the addition of MDCM to meat products could have a negative effect on the sensory properties, mainly color, flavor, and texture (Pereira et al., 2011). Nevertheless, the inexpensive cost and nutritional value, to provide the effective use of animal resources, are main reasons why studies about the effects of MDCM on the quality characteristics of meat products are still underway. Perlo et al. (2006) reported that addition of washed MDCM up to $40 \%$ increased the fat content but decreased the protein content of chicken nuggets. Therefore the objective of this study was to formulatechicken burgerby replacing chicken meat with 20,40 and $60 \%$ of gizzard or MDCM. The proximate composition, chemical, physical, microbiological quality attributes and sensory properties of chicken burger immediately after preparation and during storage at $-18 \pm 1^{\circ} \mathrm{C}$ for 6 months were evaluated.

\section{MATERIALS AND METHODS Materials \\ Chicken meat}

Broiler carcasses (7-8 weeks age with average weight $1.5-2.0 \mathrm{~kg})$ were purchased from the local market at Giza, Egypt. The chicken was slaughtered, allowed to bleed for 5 minutes, scalded for $2 \mathrm{~min}$ at $60^{\circ} \mathrm{C}$, plucked by hand, eviscerated, rinsed with tap water and deboned. On receipt at the laboratory, they were skinned, washed carefully then the chicken meat was stored at $-18 \pm 1$ oC for 24 hours and then minced coarsely using a sterilized meat mincer before used in the formulation of chicken burgers.

\section{Fresh chicken gizzard}

Fresh chicken gizzard was obtained from El-Abed mall, Banha, qalyubia Governorate, Egypt. On receipt at the laboratory in the icebox, it was washed with cold tap water and stored at $-18 \pm 1$ oC for 24 hours then minced coarsely using a sterilized meat mincer before used in the formulation of chicken burgers.

\section{Mechanically deboned chicken meat (MDCM):}

The frozen MDCM was purchased from Al-Kahera Slaughtering Company for poultry, Cairo, Egypt.

\section{Texturized soy:}

Texturized soy was obtained from the Food Technology Research Institute, Agricultural Research Center, Giza, Egypt. It was rehydrated by water at a ratio of 1:2 (w/v) and minced twice through $3 \mathrm{~mm}$ plate.

\section{Spices mixture}

The spices were purchased from the local market in Cairo, Egypt. The spices $\mathbf{6} 60.0 \%$ fennel, $27.0 \%$ coriander, $3.0 \%$ Chinese cubeb, $3.0 \%$ white pepper, $3.0 \%$ clove, $2.0 \%$ laurel leaf powder and $2.0 \%$ cardamom.) were mixed together then ground to pass through a 60 mesh sieve and kept in a tight jar.

\section{Methods:}

\section{Technological methods}

Preparation of chicken burgers:

Fresh chicken burgers were prepared as described by Mikkelson (1993) and Abd EL-Qader (2004). The control chicken burger consisted of $\mathbf{7 1 . 5 0 \%}$ minced chicken meat (included fat), $12.0 \%$ rehydrated texturized soy, $6.30 \%$ fresh eggs, $7.0 \%$ fresh onion, $1.50 \%$ salt, 
$1.70 \%$ spices. The frozen chicken meat was cut into approximately $5 \mathrm{~cm}$ cubes and minced by using meat mincer. The other ingredients were added and mixed by using a laboratory blender (Hobart Kneading machine, Italy) together. After blending, the chicken mixture was shaped manually using a patty maker (stainless steel model "Form") to obtain round discs of $10 \mathrm{~cm}$ diameter and 0.50 $\mathrm{cm}$ thickness. The other chicken burgers were formulated by replacing chicken meat with 20,40 and $60 \%$ levels of gizzard or MDCM. After the formulation of chicken burgers, it was aerobically packaged in the foam plates, wrapped with polyethylene film and stored at $18 \pm 1^{\circ} \mathrm{C}$ for 6 months. The samples were taken for analysis every month.

Analytical methods

Proximate composition:

AOAC (2012) methods were used to determine moisture, crude fat, crude protein, and total ash contents of the chicken burger. Total carbohydrate content of the chicken burger was calculated by difference.

Total volatile nitrogen (TVN):

The TVN of the chicken burger was determined by the method described by Winton and Winton (1958).

\section{Thiobarbituric acid (TBA):}

The TBA of the chicken burger was determined according to the method described by Kirk and Sawyer (1991). The TBA values were expressed as $\mathrm{mg}$ malonaldehyde/ $\mathrm{kg}$ of sample.

\section{Peroxide value (PV):}

The PV of the chicken burger was determined by the titration method according to AOAC (2012) and expressed as $\mathrm{meq} / \mathrm{kg}$ of fat.

pH values:

The $\mathrm{pH}$ values of the chicken burger were measured using a pH-meter (Jenway $3510 \mathrm{pH}$ meter) at room temperature $25 \pm 1^{\circ} \mathrm{C}$.

\section{Physical properties:}

Water Holding Capacity (WHC) and plasticity of the chicken burgers were measured according to the filter - press method of Wierbicki and Deatherage (1958). Drip loss was measured by the difference between the weight of complete frozen burger and weight of the same burger after thawing. The drip loss was calculated as the percentage of weight change (AMSA 1995).

\section{Microbiological analysis}

\section{Sample preparation:}

Ten grams of a representative and homogenized sample were mixed with 90 $\mathrm{ml}$ of sterile buffered $0.1 \%$ peptone water in a sterile blender, under sterile conditions, to give $1 / 10$ dilution. Serial dilutions were prepared to be used for counting several types of bacteria and yeast and mold counts.

\section{Bacteriological methods:}

Total bacterial count (TBC), Staphylococcus aureus, psychrophilic bacteria and yeast and mold counts of the chicken burgers were determined by using Nutrient agar, Baird-parker agar, Nutrient agar, and Potato Dextrose agar media, respectively according to the procedures described by APHA (1976) and Difco Manual (1984). Incubations were carried out at $37^{\circ} \mathrm{C} / 48 \mathrm{~h}$ for TBC; at $37^{\circ} \mathrm{C} / 24 \mathrm{~h}$ for Staphylococcus aureus, at $8^{\circ} \mathrm{C} / 5$ days for psychrophilic bacteria and $25^{\circ} \mathrm{C} / 5$ day for yeasts and molds count.

\section{Salmonella:}

The presence or absence of salmonella of the chicken burger was determined according to the methods described by FAO (1979) using buffered peptone as a pre-enrichment, while tetrathionate broth was used as a 
Mai M. El-Kordy, et al.,

selective enrichment broth and S-S agar was used as a selective plating media.

\section{Sensory evaluation:}

The thawed chicken burgers were grilled on a hot plate with little sunflower oil at $110^{\circ} \mathrm{C}$ for 4 minutes and left to cool at room temperature for $15 \mathrm{~min}$. Sensory properties of cooked chicken burgers were carried out according to Mansour and Khalil (1999) by ten-trained panelists. Randomly coded samples were served to panelists individually. Five sensory attributes were evaluated (taste, odor, color, texture, and overall acceptability) using ten points hedonic scale for each trait where 9-10 = like extremely, 7-8 = like very much, $6=$ like moderately, $5=$ neither like nor dislike, $4=$ dislike moderately, $3=$ dislike very much and 1-2 $=$ dislike extremely.

\section{Statistical analysis:}

Proximate composition of raw materials was analyzed by one-way analysis of variance. A completely randomized 2 (type of by-products) $\times 4$ (replacement levels) $\times 7$ (storage period) $\times 3$ (replication) factorial design was used for chicken burger data. An analysis of variance was conducted using Costat version 6.311 (Copyright 1998-2005, CoHort software). When a significant main effect was detected, the means were separated with the Student Newman Keuls test. The predetermined acceptable level of probability was $5 \%(P \leq 0.05)$ for all comparisons.

\section{RESULTS AND DISCUSSION}

Proximate composition and microbial load of raw materials

The chicken meat had $(p \leq 0.05)$ higher crude protein and total ash than chicken gizzard or MDCM (Table 1). The gizzard had $(p \leq 0.05)$ higher moisture and lower $(p \leq 0.05)$ crude fat than chicken meat and MDCM. The MDCM had ( $p \leq 0.05)$ higher crude fat andlower $(p \leq 0.05)$ moisture, crude protein and total ash contents than chicken meat and gizzard. A nonsignificant difference $(p>0.05)$ was observed in total carbohydrates content among the raw materials. These results are in agreement with those reported by Wattanachant et al. (2004) and Abd ElQader (2004) for chicken meat, Maiti and Ahlawat (2011) and Wani and Majeed (2014) for gizzard and Botka-Petrak et al. (2011) for MDCM.

Table (1): Proximate composition and microbial load of chicken meat, gizzard and MDCM

\begin{tabular}{lcccc}
\hline & $\begin{array}{c}\text { Chicken } \\
\text { meat }\end{array}$ & Gizzard & MDCM & LSD \\
\hline Chemical composition (\%) & & & & \\
Moisture & $73.08^{\mathrm{b}}$ & $78.96^{\mathrm{a}}$ & $69.37^{\mathrm{c}}$ & 0.71 \\
Crude protein & $19.67^{\mathrm{a}}$ & $17.13^{\mathrm{b}}$ & $15.41^{\mathrm{c}}$ & 0.43 \\
Crude fat & $5.62^{\mathrm{b}}$ & $2.65^{\mathrm{c}}$ & $14.27^{\mathrm{a}}$ & 0.32 \\
Total ash & $1.46^{\mathrm{a}}$ & $1.13^{\mathrm{b}}$ & $0.84^{\mathrm{c}}$ & 0.17 \\
Total carbohydrates & $0.17^{\mathrm{a}}$ & $0.13^{\mathrm{a}}$ & $0.11^{\mathrm{a}}$ & 0.09 \\
Microbial load (cfu/g) & & & & \\
Total bacterial & $2.71 \times 10^{4}$ & $4.35 \times 10^{3}$ & $9.2 \times 10^{4}$ & \\
Psychrophilic bacteria & $4.63 \times 10^{2}$ & $2.71 \times 10^{2}$ & $7.58 \times 10^{2}$ & \\
Staphylococcus aureas & $1.74 \times 10$ & $1.11 \times 10$ & $3.91 \times 10$ & \\
Salmonella Spp. & ND & ND & ND & \\
Yeast and mold & ND & ND & ND & \\
\hline
\end{tabular}

Means in the same row with different letters are significantly different $(p \leq 0.05)$ ND= not detected 
The total bacterial counts of chicken meat in the present study were $2.7 \times 10^{4} \mathrm{cfu} / \mathrm{g}$. The total bacterial counts of raw materials did not exceed the maximum levels $10^{5} \mathrm{cfu} / \mathrm{g}$ of microbiological criteria for fresh and frozen poultry given by Egyptian standard specifications (2009). Chicken meat, gizzard and MDCM were completely free from Salmonella spp and yeast and mold. Comparable total bacterial counts $\left(2.32-8.83 \times 10^{4} \mathrm{cfu} / \mathrm{g}\right)$ and the similar Salmonella spp and yeast and mold (not detected) of chicken breast and leg were reported by Mohammed et al. (2017). The MDCM had higher total bacterial count, psychrophilic bacteria and staphylococcus aureas than chicken meat and gizzard. The chicken meat had higher total bacterial, psychrophilic bacteria and staphylococcus aureas counts than gizzard.

\section{Proximate composition of chicken burgers}

The chicken burger formulated with gizzard had higher ( $p \leq 0.05)$ moisture, crude protein and total ash and lower ( $p \leq$ 0.05 ) crude fat than chicken burger formulated with MDCM (Table 2). The total carbohydrates content was similar $(p>0.05)$ in the chicken burgers formulated with gizzard or MDCM. The control chicken burger had higher ( $p \leq$ 0.05 ) crude protein and total ash contents and lower ( $p \leq 0.05$ ) crude fat content than chicken burger formulated with different levels of gizzard and MDCM. The Non-significant $(p>0.05)$ differences were observed in moisture and total carbohydrate contents among all burgers. The crude protein and total ash contents of chicken burgers were decreased ( $p \leq 0.05$ ) by increasing the level of gizzard and MDCM. On the contrary, the crude fat content was increased $(p \leq 0.05)$ by increasing the level of gizzard and MDCM. Maha and Hassan (2016) found that incorporation of chicken gizzards at $25 \%$ and $50 \%$ in beef sausage increased the crude fat content and decreased the total ash content. Daros et al. (2005) observed a decrease in crude protein and total ash contents in sausage with the increasing of mechanically deboned poultry meat.

The moisture content of the chicken burger was ( $p \leq 0.05)$ gradually decreased by increasing the storage period. However, total carbohydrates content had an opposite trend. The crude protein, crude fat and total ash contents were not affected $(p>0.05)$ by the storage period. The reduction of moisture content might be due to the drip loss and evaporation of moisture during frozen storage periods. The increase in total carbohydrates content was attributed to the reduction in moisture content during the storage period. Mahdavi et al. (2018) reported that the moisture content of the chicken burger was decreased in all chicken burger samples with increasing the frozen storage time.

\section{Chemical quality attributes of chicken burgers}

The total volatile nitrogen (TVN), thiobarbituric acid (TBA) and peroxide value (PV) of the chicken burgers were significantly affected $(p \leq 0.05)$ by gizzard or MDCM and their levels except for the PV. The PV was not affected $(p>0.05)$ by the levels of gizzard or MDCM (Table 3). The chicken burger formulated with MDCM had significantly higher ( $p \leq 0.05$ ) TVN, TBA and PV values than chicken burger formulated with a gizzard. This might be due to the MDCM had higher crude fat content than gizzard and chicken meat (Table 1). Bigolin et al., (2013) reported that MDCM has a high 
Mai M. El-Kordy, et al.,

content of crude fat therefore; it is very susceptible to oxidative reactions.

The control chicken burger had lower ( $p \leq 0.05$ ) TVN and TBA values than chicken burgers formulated with different levels of gizzard and MDCM. The TVN and TBA values were increased by increasing the levels of gizzard and MDCM. However, PV values were not affected ( $p$ $>0.05$ ) by the levels of gizzard and
MDCM. The acceptability recommended rate for TVN and TBA in poultry meat products are $20 \mathrm{mg} \mathrm{N} / 100 \mathrm{~g}$ and $0.9 \mathrm{mg}$ malonaldehyde/kg, respectively (Egyptian standard specifications, 2009). In the present study, TVN values (8.8$19.78 \mathrm{mg} \mathrm{N} / 100 \mathrm{~g}$ ) and TBA values (0.192$0.908 \mathrm{mg}$ malonaldehyde $/ \mathrm{kg}$ ) of all chicken burgers were within the acceptable range.

Table (2): Proximate composition of chicken burgers as affected by different types and levels of by-products during storage at $-18 \pm 1^{\circ} \mathrm{C}$ for 6 months

\begin{tabular}{|c|c|c|c|c|c|}
\hline & Moisture & $\begin{array}{l}\text { Crude } \\
\text { protein }\end{array}$ & Crudefat & Totalash & $\begin{array}{c}\text { Total } \\
\text { Carbo- } \\
\text { hydrates }\end{array}$ \\
\hline & \multicolumn{5}{|c|}{ (\%) } \\
\hline \multicolumn{6}{|c|}{ Type of by-products } \\
\hline Gizzard & $70.56^{a}$ & $17.23^{\mathrm{a}}$ & $4.15^{b}$ & $2.97^{a}$ & $5.09^{a}$ \\
\hline MDCM & $68.05^{b}$ & $16.75^{b}$ & $7.44^{a}$ & $2.88^{b}$ & $4.88^{a}$ \\
\hline LSD & 0.45 & 0.34 & 0.23 & 0.07 & 0.27 \\
\hline \multicolumn{6}{|c|}{ Level of by-products (\%) } \\
\hline 0 & $68.96^{a}$ & $17.95^{\mathrm{a}}$ & $4.98^{d}$ & $3.06^{\mathrm{a}}$ & $5.05^{a}$ \\
\hline 20 & $69.21^{\mathrm{a}}$ & $17.47^{\mathrm{b}}$ & $5.40^{c}$ & $2.99^{b}$ & $4.93^{a}$ \\
\hline 40 & $69.29^{a}$ & $16.99^{c}$ & $5.79^{b}$ & $2.93^{c}$ & $4.99^{a}$ \\
\hline 60 & $69.42^{\mathrm{a}}$ & $16.50^{d}$ & $6.19^{a}$ & $2.86^{\mathrm{d}}$ & $5.03^{a}$ \\
\hline LSD & 0.39 & 0.35 & 0.21 & 0.04 & 0.24 \\
\hline \multicolumn{6}{|c|}{ Storage period (month) } \\
\hline 0 & $69.91^{\mathrm{a}}$ & $17.21^{\mathrm{a}}$ & $5.73^{a}$ & $2.91^{a}$ & $4.25^{\mathrm{g}}$ \\
\hline 1 & $69.70^{\mathrm{b}}$ & $17.18^{a}$ & $5.71^{a}$ & $2.92^{\mathrm{a}}$ & $4.45^{f}$ \\
\hline 2 & $69.49^{c}$ & $17.16^{\mathrm{a}}$ & $5.70^{\mathrm{a}}$ & $2.93^{a}$ & $4.73^{e}$ \\
\hline 3 & $69.22^{d}$ & $17.13^{\mathrm{a}}$ & $5.68^{a}$ & $2.94^{a}$ & $5.03^{d}$ \\
\hline 4 & $69.03^{e}$ & $17.10^{\mathrm{a}}$ & $5.66^{\mathrm{a}}$ & $2.96^{a}$ & $5.26^{c}$ \\
\hline 5 & $68.81^{f}$ & $17.07^{a}$ & $5.65^{a}$ & $2.97^{a}$ & $5.50^{\mathrm{b}}$ \\
\hline 6 & $68.62^{\mathrm{g}}$ & $17.04^{\mathrm{a}}$ & $5.62^{\mathrm{a}}$ & $2.99^{a}$ & $5.73^{a}$ \\
\hline LSD & 0.18 & 0.16 & 0.09 & 0.08 & 0.15 \\
\hline
\end{tabular}

Means in the same column with different letters are significantly different $(p \leq 0.05)$ 
Quality attributes of chicken burger formulated with different levels of ..............

Table (3): Chemical quality attributes of chicken burgers as affected by different types and levels of by-products during storage at $-18 \pm 1^{\circ} \mathrm{C}$ for 6 months

\begin{tabular}{lccc}
\hline & TVN & TBA & PV \\
\hline Type of by-products & & & \\
Gizzard & $14.46^{\mathrm{b}}$ & $0.540^{\mathrm{b}}$ & $3.74^{\mathrm{b}}$ \\
MDCM & $16.69^{\mathrm{a}}$ & $0.750^{\mathrm{a}}$ & $4.38^{\mathrm{a}}$ \\
LSD & 0.29 & 0.05 & 0.13 \\
Level of by-products (\%) & & & \\
0 & $14.46^{\mathrm{d}}$ & $0.610^{\mathrm{d}}$ & $4.04^{\mathrm{a}}$ \\
20 & $15.45^{\mathrm{c}}$ & $0.621^{\mathrm{c}}$ & $4.04^{\mathrm{a}}$ \\
40 & $16.50^{\mathrm{b}}$ & $0.690^{\mathrm{b}}$ & $4.05^{\mathrm{a}}$ \\
60 & $16.78^{\mathrm{a}}$ & $0.696^{\mathrm{a}}$ & $4.10^{\mathrm{a}}$ \\
LSD & 0.22 & 0.04 & 0.16 \\
Storage period (month) & & & \\
0 & $8.80^{\mathrm{g}}$ & $0.192^{\mathrm{g}}$ & $0.32^{\mathrm{g}}$ \\
1 & $10.97^{\mathrm{f}}$ & $0.334^{\mathrm{f}}$ & $1.58^{\mathrm{f}}$ \\
2 & $13.56^{\mathrm{e}}$ & $0.498^{\mathrm{e}}$ & $2.50^{\mathrm{e}}$ \\
3 & $15.92^{\mathrm{d}}$ & $0.640^{\mathrm{d}}$ & $3.97^{\mathrm{d}}$ \\
4 & $17.10^{\mathrm{c}}$ & $0.775^{\mathrm{c}}$ & $5.60^{\mathrm{c}}$ \\
5 & $18.08^{\mathrm{b}}$ & $0.858^{\mathrm{b}}$ & $6.75^{\mathrm{b}}$ \\
6 & $19.78^{\mathrm{a}}$ & $0.908^{\mathrm{a}}$ & $7.68^{\mathrm{a}}$ \\
LSD & 0.25 & 0.02 & 0.19 \\
\hline
\end{tabular}

Means in the same column with different letters are significantly different ( $p \leq 0.05)$

The TVN, TBA and PV values of the chicken burger were significantly ( $p \leq$ 0.05) increased as the storage period increased. The increase in TVN values might be due to the bacterial breakdown during storage of chicken burger (Osheba and Abd El-Bar, 2007). The increase in TBA and PV values during the storage period might be due to continuous oxidation of lipids and consequently the production of oxidative by-products. These results are in agreement with those obtained by Mohamed (2011) who observed a significant increase in TVN and PV values of chicken burger with frozen storage ($\left.18^{\circ} \mathrm{C}\right)$ time. Mohammed et al. (2017) reported that TVN and TBA values of chicken kobeba were significantly ( $p \leq$ $0.05)$ increased as storage $\left(-18^{\circ} \mathrm{C}\right)$ period increased.

\begin{abstract}
Physical properties of chicken burgers

The $\mathrm{pH}, \mathrm{WHC}$, plasticity and drip loss of chicken burgers were significantly affected ( $p \leq 0.05$ ) by gizzard or MDCM and their levels as well as storage period except for the WHC. The WHC was not affected $(p>0.05)$ by the levels of gizzard or MDCM (Table 4). The chicken burger formulated with MDCM had significantly higher $(\mathrm{p} \leq 0.05) \mathrm{pH}$, and plasticity values and lower ( $p \leq 0.05)$ WHC and drip loss than chicken burger formulated with a gizzard.The increment of $\mathrm{pH}$ value in burger formulated with MDCM might be attributed to the incorporation of bone marrow constituents and the denaturation of protein during the mechanical deboning process.
\end{abstract}


Mai M. El-Kordy, et al.,

Table (4): Physical properties of chicken burgers as affected by different types and levels of by-products during storage at $-18 \pm 1^{\circ} \mathrm{C}$ for 6 months

\begin{tabular}{|c|c|c|c|c|}
\hline & pH & WHC & Plasticity & Drip loss \\
\hline \multicolumn{5}{|c|}{ Type of by-product } \\
\hline Gizzard & $6.42^{b}$ & $3.50^{\mathrm{a}}$ & $3.11^{b}$ & $5.67^{\mathrm{a}}$ \\
\hline MDCM & $6.81^{a}$ & $2.87^{b}$ & $3.64^{\mathrm{a}}$ & $4.62^{b}$ \\
\hline LSD & 0.19 & 0.21 & 0.29 & 0.19 \\
\hline \multicolumn{5}{|c|}{ Level of by-products (\%) } \\
\hline 0 & $6.35^{b}$ & $3.30^{\mathrm{a}}$ & $3.10^{d}$ & $5.36^{\mathrm{a}}$ \\
\hline 20 & $6.59^{a}$ & $3.27^{\mathrm{a}}$ & $3.23^{\mathrm{c}}$ & $5.12^{\mathrm{b}}$ \\
\hline 40 & $6.61^{\mathrm{a}}$ & $3.11^{\mathrm{a}}$ & $3.37^{\mathrm{b}}$ & $5.14^{\mathrm{b}}$ \\
\hline 60 & $6.67^{\mathrm{a}}$ & $3.18^{a}$ & $3.52^{\mathrm{a}}$ & $5.19^{b}$ \\
\hline LSD & 0.20 & 0.21 & 0.12 & 0.15 \\
\hline \multicolumn{5}{|c|}{ Storage period (month) } \\
\hline 0 & $6.37^{f}$ & $2.75^{\mathrm{g}}$ & $3.83^{\mathrm{a}}$ & $3.85^{\mathrm{g}}$ \\
\hline 1 & $6.41^{\text {ef }}$ & $2.88^{f}$ & $3.67^{b}$ & $4.34^{f}$ \\
\hline 2 & $6.48^{\mathrm{de}}$ & $3.05^{\mathrm{e}}$ & $3.51^{\mathrm{c}}$ & $4.71^{\mathrm{e}}$ \\
\hline 3 & $6.56^{\mathrm{cd}}$ & $3.17^{d}$ & $3.35^{\mathrm{d}}$ & $5.15^{\mathrm{d}}$ \\
\hline 4 & $6.65^{b c}$ & $3.33^{c}$ & $3.20^{\mathrm{e}}$ & $5.63^{c}$ \\
\hline 5 & $6.73^{\mathrm{ab}}$ & $3.49^{b}$ & $3.05^{f}$ & $6.06^{b}$ \\
\hline 6 & $6.80^{\mathrm{a}}$ & $3.69^{a}$ & $2.89 \mathrm{~g}$ & $6.47^{a}$ \\
\hline LSD & 0.14 & 0.11 & 0.09 & 0.16 \\
\hline
\end{tabular}

Means in the same column with different letters are significantly different ( $p \leq 0.05)$

The control chicken burger had lower $(\mathrm{p} \leq 0.05) \mathrm{pH}$ and plasticity values and higher $(p \leq 0.05)$ drip loss than chicken burgers formulated with different levels of gizzard and MDCM. A non-significant difference $(p>0.05)$ was observed in WHC between the control and other chicken burgers. The plasticity was increased $(p \leq 0.05)$ by increasing the levels of gizzard and MDCM. However, $\mathrm{pH}$ and drop loss values were not affected ( $p$ $>0.05$ ) by increasing the levels of gizzard and MDCM. The drop loss was improved by the addition of gizzard or MDCM in a chicken burger at different levels. Increasing the TVN values of chicken burger with the increasing the levels of gizzard or MDCM (Table 3) supporting the increase in their $\mathrm{pH}$ values.

The WHC and drip loss values were increased $(p \leq 0.05)$ and plasticity decreased ( $p \leq 0.05$ ) by increasing the storage period. The relationships among WHC, drip loss and plasticity values in this study were corrected. The increment of WHC values of chicken burger during storage might be attributed to protein denaturation and loss of protein solubility (Abd El-Qader, 2004). The pH values of the chicken burger were increased ( $p \leq 0.05$ ) with increasing the storage period. The 
Quality attributes of chicken burger formulated with different levels of ..............

increase of $\mathrm{pH}$ values during the storage period could be due to the breakdown of protein and formation of protein metabolites mainly amines (Reddy et al., 2013). The similar results were reported by Darwish et al. (2012) who observed that drip loss of chicken burger was progressively increased by extending the frozen storage period at $-18^{\circ} \mathrm{C}$ for 6 months.

\section{Microbial load of chicken burgers}

The microbial load of chicken burgers was affected by gizzard or MDCM and their levels as well as the storage period
(Table 5). The total bacterial counts of chicken burgers from beginning up to the end of storage did not exceed the maximum levels $10^{5} \mathrm{cfu} / \mathrm{g}$ of microbiological criteria for fresh and frozen poultry given by Egyptian standard specifications (2009). Salmonella Spp and yeast and mold were not detected in all chicken burgers during the storage period, which proved the sanitary conditions of raw materials. Mohammed et al. (2017) reported that Salmonella Spp was not detected in all kobeba during the storage period.

Table (5): Microbial load of chicken burgers as affected by different types and levels of by-products during storage at $-18 \pm 1^{\circ} \mathrm{C}$ for 6 months

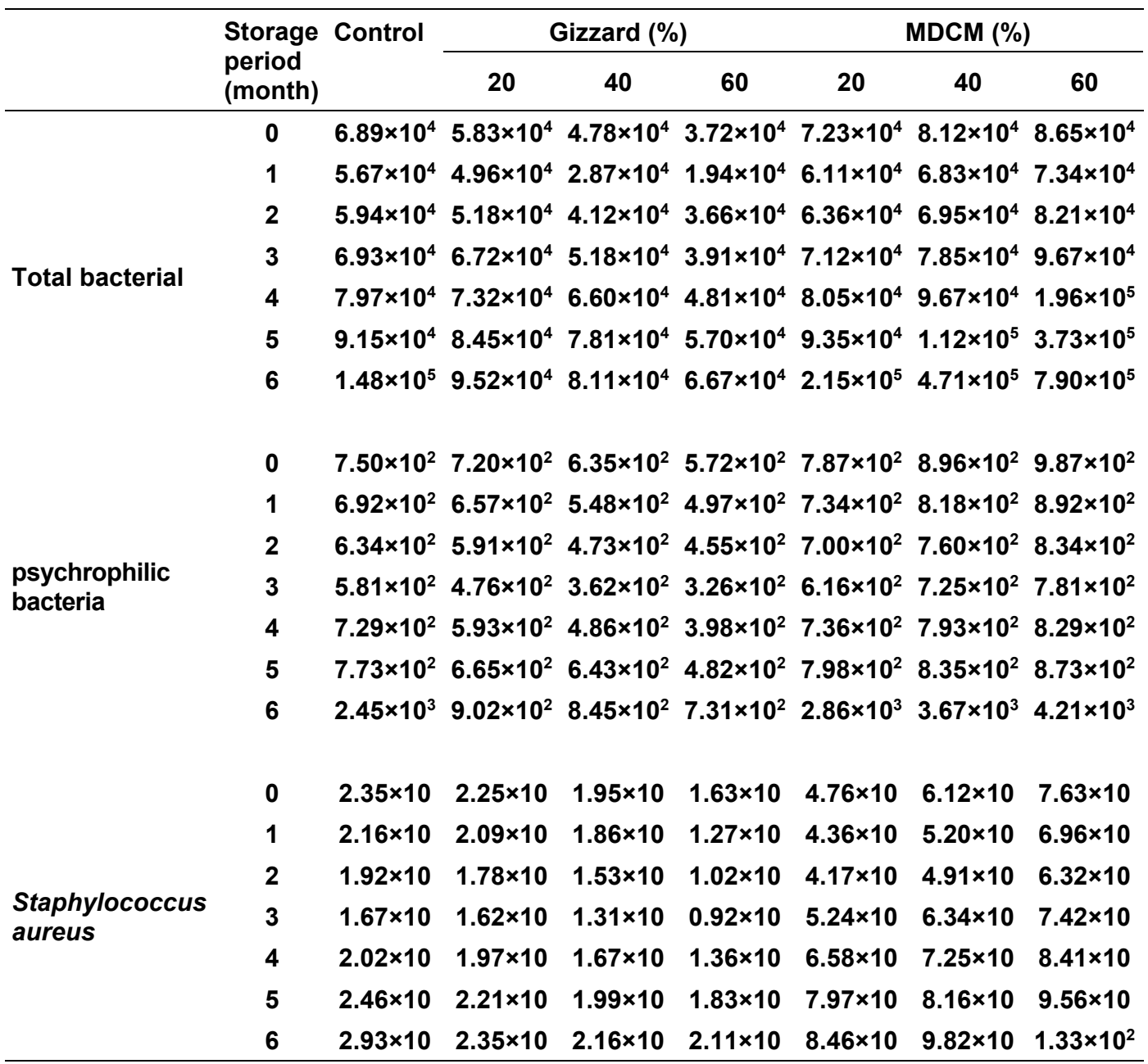

Salmonella Spp and yeast and mold not detected 
The chicken burgers formulated with different levels of gizzard had lower total bacterial, psychrophilic bacteria and Staphylococcus aureus counts than control chicken burger. These microbial loads were decreased by increasing the levels of the gizzard. However, the chicken burgers formulated with different levels of MDCM had higher total bacterial, psychrophilic bacteria and Staphylococcus aureus counts than control chicken burger. These microbial loads were increased by increasing the levels of the MDCM. This might be due to MDCM had higher microbial load than fresh raw chicken meat and raw gizzard as shown in Table (1). Mohamed and Mansour et al. (2012) reported that psychrotrophic bacteria counts of beef patties prepared with MDCM $(200 \mathrm{~g} / \mathrm{kg})$ were significantly higher than those of control beef patties.

The total bacterial counts of all chicken burgers were reduced until the first month of storage followed by a gradual increase up to the end of the storage period. The psychrophilic bacteria were reduced until the third month of storage followed by a slight increase up to the end of the storage period. The Staphylococcus aureus of chicken burgers formulated with different levels of gizzard was reduced until the third month of storage followed by a slight increase up to the end of the storage period. However, Staphylococcus aureus of chicken burgers formulated with different levels of MDCM was reduced until the second month of storage followed by a slight increase up to the end of the storage period. The reduction of microorganism counts during 1-3 months of storage might be due to the breakdown of the microorganisms cell wall by ice-crystals formed during the freezing process. After these periods of storage, the increase in microorganism counts might be due to the increasing of amino acids and fatty acids produced by hydrolysis of protein and fat during storage consequently lead to suitable conditions for the growth of microorganisms. The similar results were reported by Mohammed et al. (2017) for total bacterial and psychrophilic bacteria counts of kobeba.

\section{Sensory properties of chicken burger}

Sensory properties of chicken burgers were significantly affected ( $p \leq 0.05$ ) by gizzard or MDCM and their levels as well as storage period (Table 6). Chicken burgers formulated with gizzard had higher ( $p \leq 0.05)$ scores of taste, odor, color, texture and overall acceptability than chicken burger formulated with MDCM. The sensory properties of chicken burgers formulated with gizzard had rating scores described as like very much (7.52-8.05). However, chicken burgers formulated with MDCM had rating scores ranged between like moderately $(6.80)$ and like very much (7.03-7.64). The chicken burgers formulated with gizzard were more acceptable to Egyptians because it was usual to add gizzard in some foods.

The control chicken burger had significantly higher ( $p \leq 0.05)$ odor and color scores than chicken burgers formulated with different levels of gizzard and MDCM. The odor and color scores were decreased $(p \leq 0.05)$ by increasing the levels of gizzard and MDCM. The nonsignificant $(p>0.05)$ differences were observed in taste, texture and overall acceptability between control chicken burger and chicken burger formulated with gizzard or MDCM up to $40 \%$. The chicken burger formulated with $60 \%$ gizzard or MDCM had lower ( $p \leq 0.05$ ) taste and overall acceptability scores and 
higher $(p \leq 0.05)$ texture score than control chicken burger and chicken burger formulated with gizzard or MDCM up to $40 \%$. The control chicken burger and chicken burgers formulated with different levels of gizzard or MDCM had rating scores described as like very much (7.20-8.54). Generally, the chicken burger could be formulated up to $60 \%$ gizzard or MDCM with acceptable sensory properties.

The sensory properties of the chicken burgers were decreased ( $p \leq 0.05$ ) by increasing the storage period. The decrement of sensory properties during storage period might be due to the oxidation potential of fatty acids present in the chicken burger. At the end of the storage period, sensory properties of chicken burgers had rating scores described as like moderately (6.10-6.24). Abdelmageed et al. (2013) reported that gizzard can be incorporated into sausages with a percentage greater than $25 \%$ with acceptable quality.

Table (6): Sensory properties of chicken burgers as affected by different types and levels of by-products during storage at $-18 \pm 1^{\circ} \mathrm{C}$ for 6 months

\begin{tabular}{|c|c|c|c|c|c|}
\hline & Taste & Odor & Color & Texture & $\begin{array}{c}\text { Overall } \\
\text { acceptability }\end{array}$ \\
\hline \multicolumn{6}{|c|}{ Type of by-products } \\
\hline Gizzard & $7.90^{\mathrm{a}}$ & $7.52^{\mathrm{a}}$ & $7.99^{a}$ & $8.05^{a}$ & $7.86^{a}$ \\
\hline MDM & $7.32^{\mathrm{b}}$ & $7.03^{b}$ & $7.64^{\mathrm{b}}$ & $6.80^{\mathrm{b}}$ & $7.20^{\mathrm{b}}$ \\
\hline LSD & 0.22 & 0.21 & 0.33 & 0.23 & 0.26 \\
\hline \multicolumn{6}{|c|}{ Level of by-products } \\
\hline 0 & $7.76^{a}$ & $7.78^{a}$ & $8.54^{a}$ & $7.32^{\mathrm{b}}$ & $7.85^{a}$ \\
\hline 20 & $7.91^{\mathrm{a}}$ & $7.63^{b}$ & $8.14^{b}$ & $7.30^{\mathrm{b}}$ & $7.75^{a}$ \\
\hline 40 & $7.72^{\mathrm{a}}$ & $7.35^{\mathrm{c}}$ & $7.90^{c}$ & $7.40^{\mathrm{b}}$ & $7.59^{a}$ \\
\hline 60 & $7.20^{\mathrm{b}}$ & $7.20^{c}$ & $7.41^{\mathrm{d}}$ & $7.57^{a}$ & $7.35^{\mathrm{b}}$ \\
\hline LSD & 0.21 & 0.13 & 0.22 & 0.16 & 0.26 \\
\hline \multicolumn{6}{|c|}{ Storage period (month) } \\
\hline 0 & $8.52^{\mathrm{a}}$ & $8.43^{a}$ & $8.78^{a}$ & $8.22^{\mathrm{a}}$ & $8.49^{a}$ \\
\hline 1 & $8.34^{b}$ & $8.21^{b}$ & $8.57^{b}$ & $8.03^{b}$ & $8.29^{a}$ \\
\hline 2 & $8.06^{c}$ & $7.93^{c}$ & $8.36^{c}$ & $7.86^{c}$ & $8.05^{b}$ \\
\hline 3 & $7.79^{d}$ & $7.61^{d}$ & $8.13^{d}$ & $7.66^{d}$ & $7.80^{\mathrm{c}}$ \\
\hline 4 & $7.56^{\mathrm{e}}$ & $6.99^{\mathrm{e}}$ & $7.78^{\mathrm{e}}$ & $7.26^{\mathrm{e}}$ & $7.40^{d}$ \\
\hline 5 & $6.90^{f}$ & $6.49^{f}$ & $7.28^{f}$ & $6.76^{f}$ & $6.86^{\mathrm{e}}$ \\
\hline 6 & $6.24^{\mathrm{g}}$ & $6.10^{\mathrm{g}}$ & $6.52^{\mathrm{g}}$ & $6.06^{\mathrm{g}}$ & $6.23^{f}$ \\
\hline LSD & 0.16 & 0.21 & 0.19 & 0.15 & 0.22 \\
\hline
\end{tabular}

Means in the same column with different letters are significantly different $(p \leq 0.05)$ 


\section{Conclusion}

From the above results, it could be concluded that chicken burger formulated with gizzard or MDCM up to $60 \%$ as low-cost by-product resulted inacceptable products with good chemical, physical, microbiological and sensory properties throughout the storage period at $-18 \pm 1^{\circ} \mathrm{C}$ for 6 months.

\section{REFERENCES}

Abd El-Qader, F. M. (2004). Quality improvement of chicken frozen burger formulated with some spices or their volatile oils. M.Sc. Thesis, Food Science and Technology Dept., Faculty of Agriculture, Cairo Univ.

Abdelmageed, M. E. I., A. M. E. Sulieman, H. O. Abdalla and G. E. Salih (2013). Effects of incorporating chicken's gizzards on the fresh and stored sausage. International Journal of Food Science and Nutrition Engineering, 3: 91-94.

AMSA (1995). Research guide lines for cookery, sensory evaluation and instrumental tenderness measurements of fresh meat. Chicago, IL: American Meat Science Association.

AOAC (2012). Association of Official Analytical Chemists. $18^{\text {th }}$ edition. Gaithersburg, Maryland, USA.

APHA (1976). American Public Health Association, Compendium of Methods for the Microbiological Examination of Foods. Speck, M.L. ed., Washington D. C., USA.

Bigolin, J., C. I. Weber and A. D. T. Alfaro (2013). Lipid Oxidation in Mechanically Deboned Chicken Meat: Effect of the Addition of Different Agents. Food and Nutrition Sciences, 4: 219-223.

Botka-Petrak1, K., A. Hrast, H. Lucić1, Z. Gottstein, M. Đ. Gomerčić, S. Jakšić and T. Petrak (2011). Histological and chemical characteristics of mechanically deboned meat of broiler chickens. Vet. Arhiv, 81: 273-283.

Charonpong, G. and T. C. Chen (1980). Qualities of pickled chicken gizzard as affected by salt and vinegar. Poultry Science, 59: 537-542

Chouliara, E., A. Karatapanis, I.N. Savvaidis and M.G. Kontominas (2007). Combined effect of oregano essential oil and modified atmosphere packaging on shelf-life extension of fresh chicken breast meat stored at 4ㄷ. Food Microbiology, 24, 607-617.

Daros, F.G., M.L. Masson and S.C. Amico (2005). The influence of the addition of mechanically deboned poultry meat on the rheological properties of sausage. Journal of Food Engineering, 68: 185-189.

Darwish, S. M. I., M. A. H. El-Geddawy, R. M. B. Khalifa and R. A. A. Mohamed (2012). Physico-Chemical Changes of Frozen Chicken Burger Formulated with Some Spices and Herbs. Frontiers in Science, 2: 192199.

Difco-Manual (1984). Dehydration Culture Media and Reagents for Microbiological and Clinical Laboratory Procedures, Pub. DifcoLab., Detroit's Michigan, USA, 860 p.

Egyptian Standard Specifications (2009). Poultry meat products treated with heat. Egyptian Organization for Standardization and Quality Control, Ministry of Industry and Trade. Egypt. No 3493.

FAO (1979). Food and Agricultural Organization, Manuals of Food-Quality Control, 4, Microbiological analysis. Food and Agriculture Organization of the United Nations. Rome., 134 p.

Kirk, R. S. and R. Sawyer (1991). Pearson's Composition and Analysis of Foods. Flesh Food. 9th ed, 
Longman Scientific Technical. Inc., New York, USA, 720 p.

Kondaiah, N. and B. Panda (1987). Physicochemical and functional properties of spent hen components. Journal Food Science Technology, 24: 267-269.

Maha, M.M. and E.H. Hassan (2016). Effects of incorporating chicken's gizzards on chemical characteristics of beef sausages. American International Journal of Research in Formal, Applied and Natural Sciences, 13: 10-13.

Mahdavi, V., S. E. Hosseini and A. Sharifan (2018). Effect of edible chitosan film enriched with anise (Pimpinellaanisum L.) essential oil on shelf life and quality of the chicken burger. Food Science Nutrition, 6: 269-279.

Maiti, A. K. and S.S. Ahlawat (2011). Effect of natural tenderizers on physic-chemical properties of chicken gizzard and goat heart. American Journal of Food Technology, 6: 80-86.

Mansour, E. H. and A.H. Khalil (1999). Characteristics of low-fat beef burgers as influenced by various types of wheat fibres. Journal of the Science of Food and Agriculture, 79: 493-498.

Mikkelson, V.L. (1993). Hamburger Patty Technology: A Literature Review. Technical Report, Meat Industry Research Institute of New Zealand (Inc.), MIRINZ 932 ISSN 0465-4390.

Mohamed, H. M. H. and H. A. Mansour (2012). Incorporating essential oils of marjoram and rosemary in the formulation of beef patties manufactured with mechanically deboned poultry meat to improve the lipid stability and sensory attributes. LWT - Food Science and Technology, 45: 79-87.
Mohamed, R. A. A. (2011). Chemical and microbiological studies on some chicken meat products. M.Sc. Thesis, Faculty of Agriculture, Assiut Univ.

Mohammed, N. S., E. H. Mansour, A. S. Osheba, A. A. Hassan and A. A. ElBedawey (2017). Effect of acidic marination on the quality characteristics of spent hen kobeba during frozen storage. Arab University Journal of Agricultural Science, 25: 157-167.

Ockerman, H. W. and C. L. Hansen (2000). Edible tissue from bone: Animal byproduct processing and utilization. 1st ed. CRC Press; Boca Raton: pp. 217246.

Osheba, A. S. and N. Abd El-Bar (2007). Effect of different marinating solutions on microbial growth inhibition and quality characteristics improvement of beef slices during cold storage. Egypt. Journal of Agriculture Research, 85: 629-646.

Pereira, A. G., E. M. Ramos, J. T. Teixeira, G. P. Cardoso, A. L. S. R. Ramos and P. R. Fontes (2011). Effects of the addition of mechanically deboned poultry meat and collagen fibers on quality characteristics of frankfurtertype sausages. Meat Science, 89: 519525.

Perlo, F., P. Bonato, G. Teira, R. Fabre and S. Kueider (2006). Physicochemical and sensory properties of chicken nuggets with washed mechanically deboned chicken meat. Meat Science, 72: 785788.

Rao, V. K., B. N. Kowale and P. L. Yadav (1994). Preparation of gizzard pickle. Indian Journal Poultry Science, 29, 114-120.

Reddy, B. G.V., A. R. Sen, P.N. Nair, S. K. Reddy, K. K. Reddy and N. Kondaiah (2013). Effects of grape seed extract 
Mai M. El-Kordy, et al.,

on the oxidative and microbial stability of restructured mutton slices. Meat Science, 95: 288-294.

Wani, S. A. and D. Majeed (2014). Evaluation of quality attributes and storage stability of pickle prepared from chicken gizzard. Journal of Meat Science and Technology, 2: 85-89.

Wattanachant, S., S. Benjakul and D. A. Ledward (2004). Composition, color, and texture of thai indigenous and broiler chicken muscles. Poultry Science, 83: 123-128.

Wierbicki, E. and F.E. Deatherage (1958). Determination of water holding capacity of fresh meats. Journal Agricultural Food Chemistry, 6: 387392.

Winton, A.L and R. B. Winton (1958). Okol off Mangnesium Oxide Distillation Volumetric Methods. The Analysis of Food. John Wiley, New York and Hull, London, USA, 848 p. 
خصائص جودة برجر الاجاج المحضر بمستويات مختلفة من القانصة ولحم الاجاج

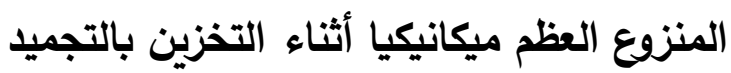

مى محمد الكردى(")، عاطف سعد عشيبة()، أمل أحمد حسن(†)، علاء الدين السيد البلتاجي(†) (1) قسم بحوث تكنولوجيا اللحوم والاسماك- معهز بحوث تكنولوجيا الاغذية- مركز البحوث الزراعية- الجيزة.

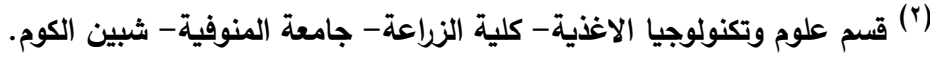

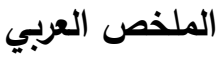

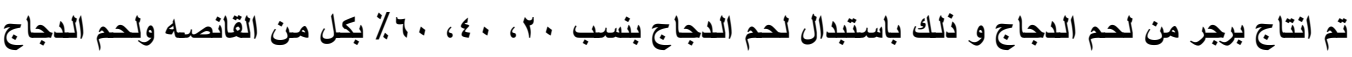

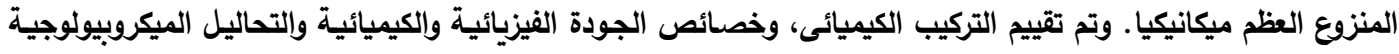

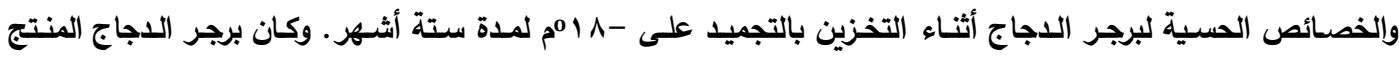

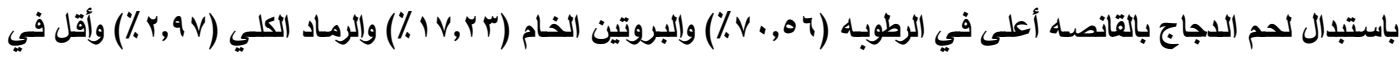

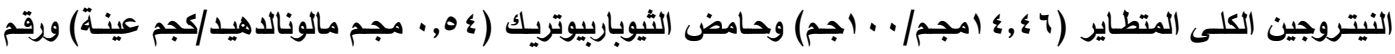

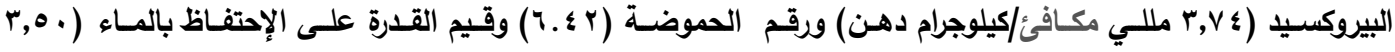

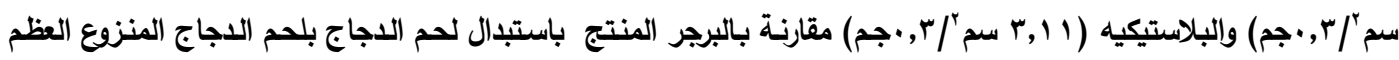

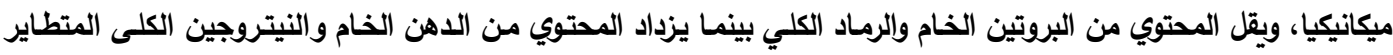

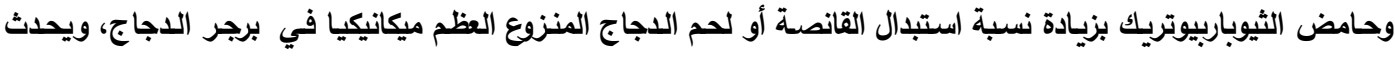

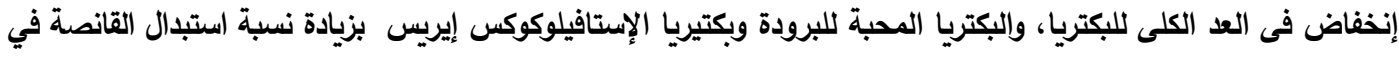

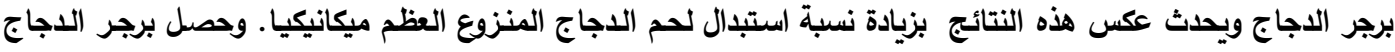

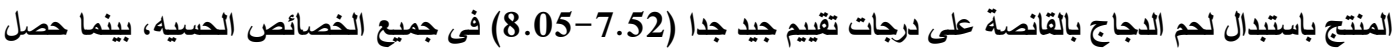

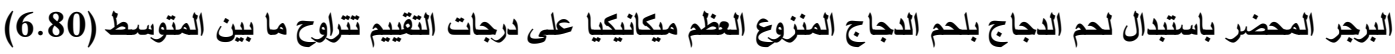

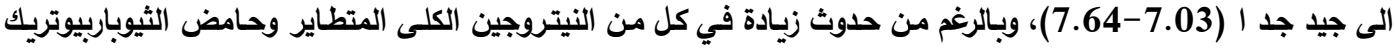

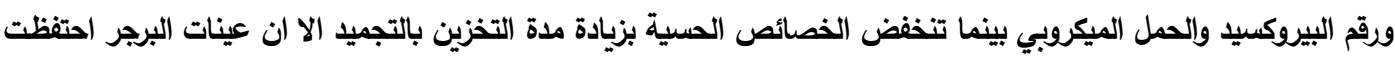

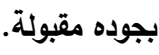
الكلمات الدالة: برجر الدجاج - لحم الاجاج - القانصة- لحم الدجاج المنزوع العظم ميكانيكيا. 